Bangladesh J. Pl. Breed. Genet., 20(1) : 01-08, 2007

\title{
EXPRESSION OF REPORTER GENES IN TRANSFORMED INDICA RICE THROUGH Agrobacterium MEDIATED METHOD
}

\author{
Shamsul H. Prodhan and A. Komamine ${ }^{1}$ \\ Laboratory of Plant Genetic Engineering, Institute of Life and Environmental Sciences, \\ University of Tsukuba, 1-1-1Tennodai, Tsukuba city \\ Ibaraki Prefecture 305-8577, Japan.
}

\begin{abstract}
Genetic transformation of rice (Oryza sativa L.) mediated by Agrobacterium tumefaciens has been confirmed for japonica varieties and extended to include more recalcitrant indica varieties. Scutellum-derived calli from mature seeds of Kasalath and BR-5 were used. The Agrobacterium tumefaciens strain, EHA101, harboring the binary vector $\mathrm{pIG} 121 \mathrm{Hm} / \mathrm{Km} / \mathrm{GUS}$ was used for transformation. The vector contains $\beta$-glucuronidase (GUS) gene as a reporter gene and hygromycin resistance (HPT) as well as kanamycin resistance gene (NPTII) as selection genes in the T-DNA region. After co-cultivation with the bacteria, calli were inoculated on selection medium in which hygromycin concentration was $50 \mathrm{mg} / \mathrm{l}$ for Kasalath and $20 \mathrm{mg} / \mathrm{l}$ for BR-5. Carbenicillin $(500 \mathrm{mg} / \mathrm{l})$ was used for removal of Agrobacterium after co-cultivation. Inclusion of acetosyringone $50-100 \mu \mathrm{M}$ in the Agrobacterium suspension in co-culture medium increased the frequency of transformation. Frequency of transformed calli (hygromycin resistant cells) was $82 \%$ in Kasalath and 6\% in BR-5. Regeneration efficiency from transformed calli in Kasalath was about $63 \%$ and in BR-5 was about $34 \%$. Most of the transgenic plants were morphologically normal but seed fertility was lower than the control. In transformed calli, roots and immature inflorescence showed positive response in GUS assay. Presence of GUS, HPT and NPTII genes was confirmed by PCR analysis and PCR Southern blot analysis. Expression of GUS gene was $100 \%$ in $\mathrm{T}_{1}$ progeny of Kasalath, whereas that of HPT gene was $51 \%$. BR-5 could not be tested because of low seed fertility of $\mathrm{T}_{0}$ plants. In $T_{1}$ plants, seed fertility of transformed Kasalath was $79 \%$ which is lower than that of the respective non-transformants.
\end{abstract}

Key words: Rice (Oryza sativa L), transformation, Agrobacterium tumefaciens, reporter gene, binary vector, acetsyringone, progeny.

\section{INTRODUCTION}

Transformation mediated by Agrobacterium tumefaciens has been used as a standard technique in plant molecular biology and genetic engineering for the transfer of foreign genes into higher plants. This technique has been primarily for dicotyledons. Monocots such as rice, wheat, corn, barley etc. are not natural hosts to Agrobacterium tumefaciens. Therefore, alternative approaches have been developed for application of recombinant DNA

1 The Research Institute of Evolutionary Biology. 2-4-28, Kamiyoga, Setagaya-ku,Tokyo, 1580098, Japan. 
techniques in cereal crop improvement. In rice protoplast mediated transformation has been reported for certain japonica and some indica rice cultivars (Shimamoto et al.1989; Datta et al. 1992). Similarly gene transfer by particle bombardment into organized tissues such as immature embryos has been used to generate transgenics of several japonica and some indica cultivars (Christou 1996).

Meanwhile, intensive investigations pertaining to the interaction between Agrobacterium and susceptible plant cells have yielded greater details of the basic processes underlying transfer of T-DNA regions. The most convincing demonstration of A. tumefaciens-mediated transformation of rice was made by Hiei et al. in 1994. Similar transformation efficiency, routinely possible for dicotyledonous plants, was achieved in rice by using A. tumefaciens strain (LBA4404) that carried a 'superbinary' vector (pTOK233) having $\operatorname{vir} \mathrm{B}, \operatorname{vir} \mathrm{C}$, and $\operatorname{vir} \mathrm{G}$ genes from the supervirulent Ti plasmid, pTiBo542 (Hood et al. 1986; Jin et al. 1987; Komari 1990). The Agrobacterium approach is emerging as an efficient transformation system for japonica and javanica rice cultivars (Hiei et al. 1994; Dong et al. 1996; Cheng et al. 1998), largely due to their improved ability of in vitro culture. However, successes with the relatively recalcitrant indica cultivars are only a few (Rashid et al. 1996; Aldmetia and Hodges 1996 and Khanna and Raina 1999).

The present study was undertaken with the objective of extending the host range of $A$. tumefaciens to certain recalcitrant indica varieties (Kasalath and BR-5) evaluating the possibility of achieving high transformation efficiencies for routine use. Expression of reporter genes in $\mathrm{T}_{0}$ and $\mathrm{T}_{1}$ plants are also described.

\section{MATERIALS AND METHODS}

\section{Transformation}

Mature seeds of two indica rice varieties Kasalath (an indigenous cultivar in eastern part of India, Assam) and BR-5 (one the leading varieties in Bangladesh) were used as explants. The infection of the rice calli were carried out using Agrobacterium tumefaciens strain EHA101 harboring the plasmid pIG121 Hm/GUS (Hiei et al. 1994). pIG121Hm/GUS is a binary vector containing hygromycin resistance gene (HPT), $\beta$-glucoronidase gene (GUS), as well as kanamycin resistance gene (NPTII) within the T-DNA region,. The gene for GUS has an intron in the 5 end of the coding sequence and is connected to the $35 \mathrm{~S}$ promoter of cauliflower mosaic virus, there by producing expression in A. tumefaciens (Fig.1).

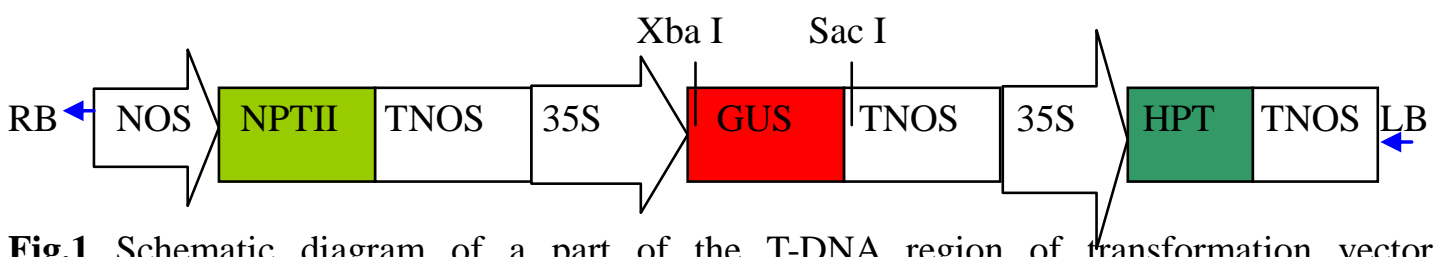

Fig.1 Schematic diagram of a part of the T-DNA region of transformation vector pIG121Hm/GUS, NOS, nopaline synthatase; NPTII, gene for neomycin phosphotransferase; TNOS, terminator of nopaline synthatase; $35 \mathrm{~S}$, 35S promoter of cauliflower mosaic virus; GUS, gene for $\beta$-glucoronidase; HPT, gene for hygromycin phosphstransferase.

Mature seeds were dehusked, washed by tap water and surface sterilized following the methodology described by Prodhan et al. (2001) and cultured on CI mediumm, (Table 1). Nine $\mathrm{cm}$ diameter Petri plates were used for the experiment which was sealed with parafilm 
(American National Can TM, USA). The cultures were incubated in the biotron at $27^{\circ} \mathrm{C}$ in 12 hours light and dark condition for 3 weeks. The proliferated calli derived from the scutella were separated with scalpel and subcultured to the fresh CI medium. Granular compact calli after 4-5 weeks (1-2 $\mathrm{mm}$ in diameter) were taken for transformation and regeneration purpose.

Preculture of Agrobacterium in YM medium and pretreatment of calli were for 3 days in a fresh CI medium. Later on co-culture were carried out in CI-AS medium for 3 days at $27^{\circ} \mathrm{C}$. After co-cultivation, calli were washed several times with sterile milliQ water and finally washed with N6-D liquid medium (Chu et al. 1975) containing $500 \mathrm{mg} / \mathrm{l}$ carbenicillin to kill the Agrobacterium and then transferred to CI-HmCb medium (Table 1) for selection purpose. Proliferated cells on CI-HmCb medium were considered as transformed calli which were later transferred to regeneration medium $\mathrm{RE}-\mathrm{HmCb}$. The regenerated shoots were further transferred REHF-HmCb medium for full plant formation with extensive root system. After rooting, the transgenic plants were acclimatized in pots $(15 \mathrm{~cm}$ diameter $)$ soil and submerged with water in a growth incubator at $30^{\circ} \mathrm{C}$ (light phase) and $25^{\circ} \mathrm{C}$ (dark phase) with 12 hours light at $71 \mu$ mole. $\mathrm{m}^{-2} \cdot \mathrm{s}^{-1}$ photon flux density and $62 \%$ relative humidity. After 2-3 weeks, transgenic plants were transferred to new pots and grown up to maturity. From these $\mathrm{T}_{0}$ plants 5 to 10 panicle were taken randomly and seed fertility were measured.

\section{GUS assay}

Histochemical and flourimetric enzyme assays to detect and quantify GUS activity were performed as described by Jefferson (1987) on calli 3 days just after co-culture with $A$. tumefaciens and again after 4 weeks of inoculation. Regenerated plant tissues were also treated with X-gluc solution and number of blue spots were counted.

\section{Genomic DNA isolation and PCR analysis}

Genomic DNA was extracted from young leaf tissues of both transgenic and untransformed control rice plants by CTAB method (Murry and Thompson 1980). To confirm the presence of GUS, HPT and NPTII genes in the transgenic plants, PCR analysis was carried out in a $50 \mu \mathrm{l}$ reaction mixture containing DNA $(1 \mu \mathrm{g}), 200 \mu \mathrm{M}$ of dNTP mixture, $1 \mu \mathrm{M}$ each of forward and reverse primers, 1 unit of Taq DNA polymerase, and $10 \mathrm{X}$ Ex Taq buffer. The standard reaction conditions used were: $94^{\circ} \mathrm{C}$ for 5 minutes followed by 30 cycles of $94^{\circ} \mathrm{C}$ for 1 minute, $60^{\circ} \mathrm{C}$ for 1 minute and $72^{\circ} \mathrm{C}$ for 1 minute. This was followed by one cycle of 15 minutes at $72^{\circ} \mathrm{C}$. The reactions were carried out in a Perkin Elmer Gene Amp PCR system 9700. Amplification for GUS gene was performed with primer GUS-4 (AGGCTGTAGCCGACGATG) and GUS-F (ATCACCGAATACGGCGTGGA). Primers used for NPTII gene were NPT-5 (GCTTGGGTGGAGAGGCTATT) and NPT-7 (CTCTTCAGCAATATCACGGG). Primers used for the detection of HPT sequences were HPH-1 GCTGGGGCGTCGGTTTCCACTATCCG and HPH-2 CGCATAACAGCGCTCATTGA CTGGAGC.

\section{PCR Southern Hybridization}

PCR with GUS primers were done for variety Kasalath and BR-5. Then the amplified product was separated on a $1 \%$ agarose gel by electrophoresis and blotted on to a positively charged nylon membrane (Amersham) according to manufacturer's instruction. The DNA was fixed to the membrane by baking at $80^{\circ} \mathrm{C}$ for 30 minutes and hybridized to GUS probe. 
The probe for the GUS gene was $1.8 \mathrm{~kb}$ fragment of the GUS gene coding region.

\section{Progeny test}

$\mathrm{T}_{1}$ progenies were obtained from $\mathrm{T}_{0}$ transgenic plants of by selfing. $\mathrm{T}_{1}$ seeds were sown on soil in a tray and after 3 weeks seedlings were transferred to $15 \mathrm{~cm}$ diameter pots in soil, submerged with water and placed in a growth incubator under the same conditions mentioned earlier. Seeds were harvested and by counting the filled and unfilled seeds fertility were measured. After harvesting the $\mathrm{T}_{1}$ seeds, growing on hygromycin included medium segregation of transgenes were checked. Roots and leaves of $T_{1}$ plants were again subjected to histochemical GUS assay to confirm the presence of the reporter gene.

\section{RESULTS AND DISCUSSIONS}

The composition of the culture medium is an important factor for the efficiency of transformation. When co-cultivation was carried out for several days in liquid medium with rice calli, the transient expression of GUS was very low (Hiei et al. 1994). In the present study, similar medium solidified with gelling agent was found better for co-cultivation than liquid medium.

Table 1. Media used for transformation by Agrobacterium mediated method

\begin{tabular}{|c|c|}
\hline Medium & Composition \\
\hline $\mathrm{CI}$ & $\begin{array}{l}\text { N6 salts and vitamins (Chu et al. } 1975 \text { ), } \\
30 \mathrm{~g} / \mathrm{l} \text { sucrose, } 28.78 \mathrm{~g} / \mathrm{l} \text { proline, } 0.3 \mathrm{~g} / \mathrm{l} \text { casamino } \\
\text { acid, } 2 \mathrm{mg} / 1 \text { 2,4-D, } 4 \mathrm{~g} / \mathrm{l} \text { gelrite and } \mathrm{pH} 5.8\end{array}$ \\
\hline CI liquid & $\begin{array}{l}\text { N6 salts and vitamins, } 30 \mathrm{~g} / 1 \text { sucrose, } 28.78 \mathrm{~g} / \mathrm{l} \\
\text { proline, } 0.3 \mathrm{~g} / \mathrm{l} \text { casamino acid and } 2 \mathrm{mg} / 12,4-\mathrm{D}\end{array}$ \\
\hline YM & Liquid YM medium, $50 \mathrm{mg} / \mathrm{l} \mathrm{Hm}$ and $50 \mathrm{mg} / \mathrm{l} \mathrm{Km}$ \\
\hline CI-AS & $\begin{array}{l}\text { CI medium, } 20 \mathrm{~g} / 1 \text { sucrose, } 1 \mathrm{mg} / 12,4-\mathrm{D} \text {, } \\
0,5,10 \mathrm{mg} / \mathrm{l}(0,50,100 \mu \mathrm{M}) \text { acetosyringone }\end{array}$ \\
\hline $\mathrm{CI}-\mathrm{HmCb}$ & $\begin{array}{l}\text { CI with hygromycin }(50 \mathrm{mg} / \mathrm{l} \text { for Kasalth and } \\
20 \mathrm{mg} / \mathrm{l} \text { for BR-5 ) and } 500 \mathrm{mg} / \mathrm{l} \text { carbenicillin }\end{array}$ \\
\hline $\mathrm{RE}-\mathrm{HmCb}$ & $\begin{array}{l}\text { MS salts and vitamins (Murashige and Skoog,1962), } 30 \mathrm{~g} / \mathrm{l} \\
\text { sorbitol, } 30 \mathrm{~g} / \mathrm{l} \text { sucrose, } 2 \mathrm{~g} / \mathrm{l} \text { casamino acids, } 50,30 \text { and } \\
20 \mathrm{mg} / \mathrm{l} \mathrm{hygromycin}, 500 \mathrm{mg} / \mathrm{l} \text { carbenicillin, } 2 \mathrm{~g} / \mathrm{l} \text { casamino acids, } \\
0.2 \mathrm{mg} / \mathrm{l} \mathrm{NAA,} 2 \mathrm{mg} / \mathrm{l} \mathrm{kinetin} \text { for Kasalath and } 0.2 \mathrm{mg} / \mathrm{l} \mathrm{NAA} \text {, } \\
1.5 \mathrm{mg} / \mathrm{l} \mathrm{BAP} \mathrm{for} \mathrm{BR-5,} 4 \mathrm{~g} / \mathrm{l} \text { gelrite and } \mathrm{pH} 5.8\end{array}$ \\
\hline $\begin{array}{l}\text { REHF- } \\
\mathrm{HmCb}\end{array}$ & $\begin{array}{l}\text { MS salts and vitamins, } 30 \mathrm{~g} / \mathrm{l} \text { sorbitol, } 30 \mathrm{~g} / \mathrm{l} \text { sucrose } \\
2 \mathrm{~g} / \mathrm{l} \text { casamino acids, } 50,30 \text { and } 20 \mathrm{mg} / \mathrm{l} \text { hygromycin, } \\
500 \mathrm{mg} / \mathrm{l} \text { carbenicillin, } 4 \mathrm{~g} / \mathrm{l} \text { gelrite and } \mathrm{pH} 5.8 \text {. }\end{array}$ \\
\hline
\end{tabular}

Frequencies of hygromycin resistant calli were observed for the variety Kasalath and BR-5 at 2 concentrations of acetsyringone along with control in CI-AS medium (Table 2). In both Kasalath and BR-5 hygromycin resistant cell frequency was highest in $100 \mu \mathrm{M}(10$ $\mathrm{mg} / \mathrm{l}$ ) concentration. Kasalath showed higher transformation frequency than BR-5. Addition of acetosyringone clearly increased transformation efficiency (Table 2). 
Table 2. Transformation efficiency expressed by the frequency of hygromycin resistant calli on selection medium

\begin{tabular}{|c|c|c|c|c|c|}
\hline \multirow[b]{2}{*}{ Cultivar } & \multirow[b]{2}{*}{$\begin{array}{l}\text { Hygromycin } \\
\text { conc. } \\
\text { (mg/l) }\end{array}$} & \multirow[b]{2}{*}{$\begin{array}{l}\text { Calli } \\
(\mu \mathrm{M})\end{array}$} & \multicolumn{2}{|c|}{$\begin{array}{c}\text { Number of scutellum derived } \\
\text { calli }\end{array}$} & \multirow[b]{2}{*}{$\begin{array}{c}\text { Frequency } \\
\qquad \begin{array}{c}(\%) \\
(\mathrm{B} / \mathrm{A})\end{array}\end{array}$} \\
\hline & & & $\begin{array}{l}\text { Inoculated in } \\
\text { selection } \\
\text { medium } \\
\text { (A) }\end{array}$ & $\begin{array}{l}\text { Hygromycion } \\
\text { resistant cells } \\
\text { (B) }\end{array}$ & \\
\hline \multirow{3}{*}{ Kasalath } & \multirow{3}{*}{50} & 0 & 50 & 6 & 12 \\
\hline & & 50 & 70 & 30 & 43 \\
\hline & & 100 & 128 & 105 & 82 \\
\hline \multirow{3}{*}{ BR-5 } & \multirow{3}{*}{20} & 0 & 50 & 2 & 4 \\
\hline & & 50 & 75 & 2 & 3 \\
\hline & & 100 & 172 & 10 & 6 \\
\hline
\end{tabular}

This study also suggests that acetosyringone is needed for transformation of indica rice where higher concentration was better than lower concentration. This result is similar to that reported by Hiei et al. (1994) in japonica rice and Rashid et al. (1996) with indica rice Basmati-370. Chan et al. (1993) indicated that co-cultivation of potato suspension cells (PSC) which is rich in acetosyringone and sinapic acid improved transformation efficiency of rice. Previously very low transformation efficiency was observed when acetosyringone was omitted from the co-cultivation medium (Hiei et al. 1997). Hiei et al. (1994) described that prior to infection, preculture of calli in new medium for 4 days was in important step for japonica rice transformation. They observed that, direct use of cells in suspension cultures for co-cultivation without preculture gave low frequencies of transient GUS expression and low stable transformation.

Hiei et al. (1997) also pointed out that, efficient gene transfer to monocot plants is possible if the explant tissue contains 'competent' cells that are susceptible to the infection by $A$. tumefaciens. Here we infected the granular compact calli with a binary vector pIG121Hm (Fig.1) which is derived from a most common binary vector, pBI121 (Ohta et al. 1990). Rashid et al. (1996) used the same vector to obtain transgenic Basmati rice. It has been reported that, a super binary vector, in which a DNA fragment from the virulence region was introduced in to a binary vector, was more effective for transformation of rice and they also described that recalcitrant cultivars can more easily be transformed by using this super binary vector (Hiei et al. 1994). In this study a conventional binary vector was used to obtain high transformation frequency from recalcitrant indica rice cultivars. Hashizume et al. (1999), also obtained high transformation frequencies using a conventional binary vector.

In this study very strong GUS expression was observed in the variety Kasalath (97$100 \%$ ). Strong GUS expression (60-64\%) was also observed in BR-5, which is similar to that observed by Rashid et al. (1996) in Basmati 370. High expression was also observed in the $T_{1}$ progeny. This may be due to the presence of intron in the 5' end of GUS gene of pIG121Hm. In both the varieties higher GUS expression was observed when calli were cultured in medium supplemented with higher concentration of acetosyringone which is similar to that observed with hygromycin resistant calli. 
Table 3. Regeneration frequency of transgenic Kasalath and BR-5 calli cultured in media supplemented with different acetosyringon concentration

\begin{tabular}{l|c|c|c|c|c}
\hline Genotype & $\begin{array}{c}\text { Acetosyringone } \\
\text { Conc. }(\mu \mathrm{M})\end{array}$ & $\begin{array}{c}\text { No. of calli } \\
\text { inoculated in } \\
\text { regeneration } \\
\text { medium* } \\
\text { (A) }\end{array}$ & $\begin{array}{c}\text { No. of } \\
\text { green } \\
\text { spots } \\
\text { after two } \\
\text { weeks }\end{array}$ & $\begin{array}{c}\text { Shoot } \\
\text { number } \\
\text { after four } \\
\text { weeks (B) }\end{array}$ & $\begin{array}{c}\text { Regeneration } \\
\text { Frequency } \\
(\%)(B / A)\end{array}$ \\
\hline Kasalath & 50 & 35 & 25 & 18 & 51 \\
\hline BR-5 & 100 & 35 & 30 & 22 & 63 \\
\hline
\end{tabular}

* Calli inoculated in 2 petriplates, each plate having 10 to 25 calli.

High regeneration efficiency (Table 3) was observed in Kasalath (51-63\%) which was as high as in some japonica cultivars (Hiei et al. 1994) and the indica cultivar Basmati 370 (Rashid et al. 1996). This high regeneration may be due to one key factor, which is the use of a selectable agent (hygromycin) that did not impair the regeneration potential of the cells (Ayers and Park 1994). Lower regeneration frequency (26-34\%) in the cultivar BR-5 might have been caused due to the adverse effect of Agrobacterium infection or due to varietal difference.

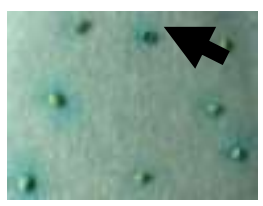

(a) Kasalath

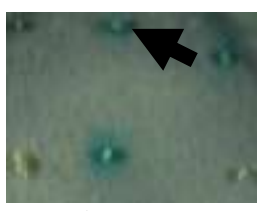

(b) BR-5

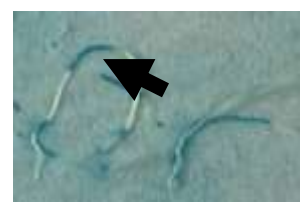

(c) Kasalath

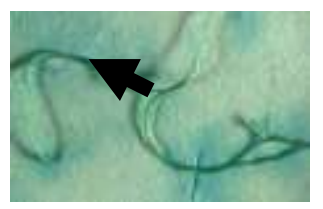

(d) BR-5

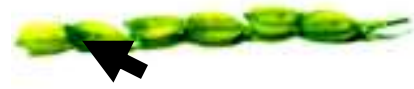

(f) BR-5

Fig 2. Histochemical GUS assay of transformed calli, roots and inflorescence of rice plants.

All the regenerated plants exhibited normal phenotypic growth with usual life cycle. They flowered and set seeds. Seed fertility was $95.9 \pm 3.0 \%$ for Kasalath and $35.4 \pm 21.8 \%$ in BR-5. Roots of mature $\mathrm{T}_{0}$ plants and inflorescence also showed GUS positive response. (Fig.2c,d,e,f). This may be due to genotypic effect and also presence of intron GUS gene. 


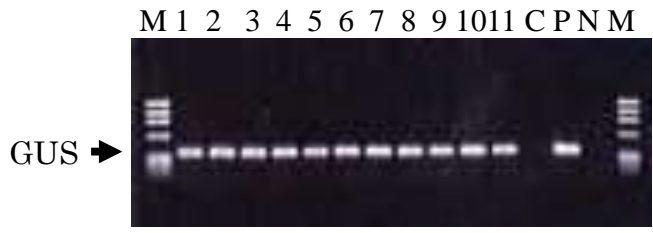

(a)

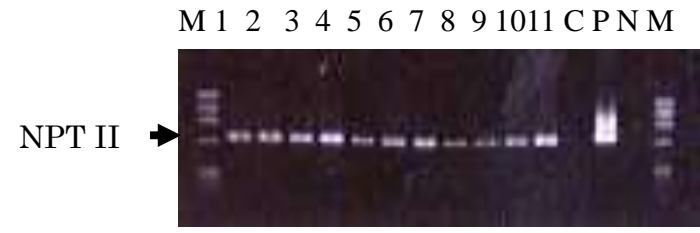

(b)

$\begin{array}{lllllllllllllll}\mathrm{P} & \mathrm{N} & \mathrm{C} & 1 & 2 & 3 & 4 & 5 & 6 & 7 & 8 & 9 & 10 & 11 & \mathrm{M}\end{array}$

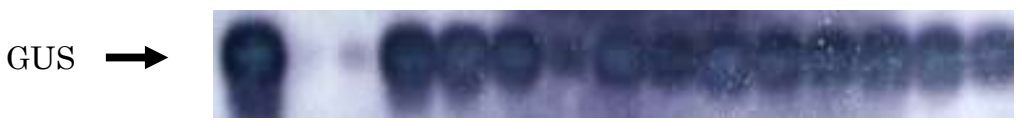

(c)

Fig.3. PCR amplification from the genomic DNA of transgenic Kasalath and BR-5 plants showing expected (a)GUS (between 310 and $610 \mathrm{bp}$ ), (b) NPTII fragments (between $603-700 \mathrm{bp}$ ) and (c ) PCR Southern Hybridization of Kasalath and BR-5. Expected GUS fragment is between 310 and 610 bp. M, marker Hae III; lane 1-6 transgenic Kasalath; lane 7-11 transgenic BR-5; C control; P positive control; N negative control.

PCR analysis was carried out for the $\mathrm{T}_{0}$ plants of Kasalath and BR-5. The plants examined showed the presence of GUS and NPTII (Fig. 3 a, b) fragments. Presence of GUS fragment was further confirmed by PCR southern blot analysis (Fig.3, c). Most of the plants roots of $\mathrm{T}_{1}$ Kasalath and BR-5 were fully GUS positive and showed blue spots on their leaves.

Percentage of hygromycin resistant $\mathrm{T}_{1}$ plants was $51 \%$ in Kasalath and $6 \%$ in BR-5. In histochemical GUS assay of Kasalath, all hygromycin resistant plant roots showed blue staining whereas the control plants showed no blue staining at all. Segregation of hygromycin resistant plants were confirmed which did not exhibit a Mendelian segregation ratio. It is not clear why the segregation of transgene in $T_{1}$ plants was deviated from Mendelian law. The lack of hygromycin resistance gene may indicate that foreign DNA was either absent or present but non-functional

Reproducible and efficient transformation methodologies have been successfully established in rice (Hiei et al., 1994), corn (Ishida et al., 1996) etc. Inheritance of foreign gene to the progeny has been reported in Japonica rice (Shimamoto et al. 1989; Chan et al. 1993; Hiei et al. 1994). For indica rice Rashid et al. (1996) also demonstrated the stable transmission of inheritance in $\mathrm{T}_{1}$ progeny. This is the first report for transformation with reporter genes for the variety BR-5. This technique is faster and will be easier to adapt in developing countries where transformation is needed to improve local rice varieties with desired genes.

\section{Acknowledgments}

We thank to Dr. H. Morishima, Professor of Genetics and Plant Breeding, Tokyo University of Agriculture, Japan and Dr. T. Fujimura, Professor of Genetic Engineering, University of Tsukuba, Japan for their valuable discussion and technical assistance. We also thank to Dr. A. Mannan, BSRI, Bangladesh for his advice and precious suggestions This research was conducted while the author was a Ph. D student in Tokyo University of Agriculture under the support of Japan Government Scholarship.

\section{REFERENCES}

Aldemita, R. R. and T. K. Hodges. 1996. Agrobacterium - mediated transformation of Japonica and Indica rice varieties. Planta 199: 612-617. 
Ayers, N. M. and D. Park. 1994. Genetic transformation of rice. Crit. Rev. Plant Sci.13:219- 239.

Chan, M. T., H. H. Chang, S. L. Ho, W. F. Tong and S. M. Yu. 1993. Agrobacterium-mediated production of transgenic rice plants expressing a chimeric $\alpha$-amylase promoter $/ \beta$ glucuronidase gene. Plant Mol. Biol. 22:491-506.

Cheng, X., R. Sardana, H. Kaplan, and I. Altosar. 1998. Agrobacterium - transformed rice plants expressing synthetic cryIA(b) and $\operatorname{cryIA}(c)$ genes are highly toxic to striped stem borer and yellow stem borer. Proceeding of the National Academy of Science USA 95, 2767-2772.

Christou, P. 1996. Transformation technology. Trends Plant Sci. 1: 423-431.

Chu, C. C., C. C. Wang, C. S. Sun, C. Hsu, K. C. Yin, C. Y. Chu and F. Y. Bi. 1975. Establishment of an efficient medium for anther culture of rice through comparative experiments on the nitrogen sources. Sci. Sin. 16: 659-688.

Datta, S. K., K. Datta, N. Soltanifar, G. Donn and I. Potrykus. 1992. Herbicide- resistant indica rice plants from IRRI breeding line IR72 after PEG mediated transformation of protoplasts. Plant Mol. Biol. 20: 619-624.

Dong, J., W. Teng, W. G. Buchholz and T. C. Hall. 1996. Agrobacterium mediated transformation of Javanica rice. Molecular Breeding 2: 267-276.

Hashizume, F., T. Tsuchiya, M. Ugaki, Y. Niwa, N. Tachibana and Y. Kowyama. 1999. Efficient Agrobacterium mediated transformation and the usefulness of a synthetic GFP reporter gene in leading varieties of Japonica rice. Plant Biotechnology, 16(5): 397-401.

Hiei, Y., T. Komari and T. Kumashiro. 1994. Efficient Transformation of rice (Oryza sativa L.) mediated by Aagrobacterium tumefaciens and sequence analysis of the boundaries of the TDNA. The Plant Journal 6(2): 271-281.

Hiei Y., T. Komari and T. Kubo. 1997. Transformation of rice mediated by Agrobacterium tumefaciens. Plant Mol. Biol. 35: 205-218.

Hood, E. E., G. L. Helmer, R. T. Freiley and M. D. Chilton. 1986. The Hypervirulence of Agrobacterium tumefaciens is encoded in a region of pTiBo542 outside of T-DNA. Journal of Bacteriology. 168: 1291-1301.

Ishida, Y., H. Saito, S. Ohta, Y. Hiei, T. Komari and T. Kumashiro. 1996. High efficiency transformation of maize (Zea mays L.) mediated by Agrobacterium tumefaciens. Nature Biotechnol. 14: 745-750.

Jeffreson, R. A. 1987. Assaying chimeric genes in plants: the GUS gene fusion system. Plant Mol. Biol. Rep.5: 387-405.

Jin, S., T. Komari, M. P. Gordon and E. W. Nester. 1987. Genes responsible for the supervirulence phenotype of Agrobacterium tumefaciens A281 Journal of Bacteriology 169, 4417 - 4425.

Khanna, H. K. and S. K. Raina. 1999. Agrobacterium - mediated transformation of indica rice cultivars using binary and superbinary vectors. Plant Physiol. 26: 311- 324.

Komari, T. 1990. Transformation of cultured cells of Chenopodium quinoa by binary vectors that carry a fragment of DNA from virulence region of pTiBo542. Plant Cell Reports. 9: 303- 306.

Murray, M. G. and W. F. Thompson. 1980. Rapid isolation of high molecular weight plantDNA. Nuc. Acids Res. 8: 4321-4325.

Ohta, S. S. Mita, T. Hattori and K. Nakamura. 1990. Construction and expression in tobacco of a $\beta$ glucuronidase (GUS) reporter gene containing an intron within the coding sequence. Plant Cell Physiol. 31: 805-813.

Prodhan, S. H., K. Nagamiya, A. Komamine and Y. Hirai. 2001. Regeneration response of indica and japonica rice in different media. Bangladesh J. Pl. Breed Genet. 14(2):1-6.

Rashid, H., S. Yokoi, K. Toriyama and K. Hinata. 1996. Transgenic plant production mediated by Agrobacterium in Indica rice. Plant Cell Reports. 15: 727-730.

Shimamoto, K., R. T. Terada, T. Izawa and H. Fujimoto. 1989. Fertile transgenic rice plants regenerated from transformed protoplasts. Nature. 238: 274-276. 